Research Article

\title{
Performance Evaluation of Cement-Stabilized Oil Shale Semicoke as Base or Subbase Course Construction Material
}

\author{
Guojin Tan $\mathbb{D}^{1},{ }^{1}$ Zhiqing Zhu, ${ }^{1}$ Yafeng Gong $\mathbb{D}^{1},{ }^{1}$ Chenglin Shi, ${ }^{2}$ and Ziyu Liu ${ }^{1}$ \\ ${ }^{1}$ College of Transportation, Jilin University, Changchun, Jilin 130025, China \\ ${ }^{2}$ Jilin Provincial Transport Scientific Research Institute, Changchun, Jilin 130012, China
}

Correspondence should be addressed to Yafeng Gong; gongyf@jlu.edu.cn

Received 27 November 2017; Accepted 25 March 2018; Published 22 April 2018

Academic Editor: Jun Liu

Copyright (c) 2018 Guojin Tan et al. This is an open access article distributed under the Creative Commons Attribution License, which permits unrestricted use, distribution, and reproduction in any medium, provided the original work is properly cited.

Oil shale semicoke is a hazardous byproduct in oil shale retorting process. In Jilin province, China, abundant oil shale resources are mainly used for retorting shale oil accompanying with a large number of oil shale semicoke slags, which will generally cause environmental pollution and disposal problems. If oil shale semicoke can be utilized as a road base or subbase course construction material, it will be a great help to the disposal of a long-term accumulated oil shale semicoke in landfill sites. Moreover, the resource treatment of oil shale semicoke in road project construction could obtain positive social and economic benefits. Subsequently, we conducted a series of laboratory tests to study the practicability of cement-stabilized oil shale semicoke as a road base or subbase course construction material, including the raw material test, modified compaction test, unconfined compressive strength (UCS) test, splitting tensile strength (STS) test, compressive resilient modulus (CRM) test, and freezing-thawing test. In this paper, test results were compared with the technical requirements of Chinese road base construction specification, preliminarily confirming that cement-stabilized oil shale semicoke can be used as a subbase course material of a highway or a base course material of a low-grade highway.

\section{Introduction}

The worldwide petroleum industry is now making a historic leap from conventional to unconventional oil and gas. Oil shale is one of the most important sources of unconventional oil and gas, and the shale oil extracted from oil shale is an ideal alternative energy source and has broad prospects [1]. China is one of the largest producers for unconventional oil extracted from oil shale. The oil shale resources in China are mainly distributed in Jilin, Liaoning, and Guangdong provinces. Oil shale can yield shale oil, retorting gas, and semicoke by retorting technology [2, 3]. Natural oil shale has high mineral composition, so the retorting solid byproduct, that is, oil shale semicoke, is usually in good integrity of rock. Owing to the absence of efficient disposal techniques, landfill is always adopted to dispose of oil shale semicoke. However, this method not only occupies much land resource but also causes great hazards to environment [4-7].

A good solution for disposing of semicoke is partly recycling to burn it as a low-grade fuel, which needs to cocombusted with some high calorific fuels at a certain rate in the circulating fluidized bed combustor. Another common utilization of semicoke is to reprocess it as a raw material of fertilizers and construction products [8-16]. All these processes are complex, and the treatment costs are relatively high. However, the abovementioned methods to dispose of oil shale semicoke are not mature enough to be widely applied currently, and the consumption of semicoke is very limited. Thus, the remainder is still a waste requiring large disposal areas, causing land and environmental problems. The main chemical compositions of oil shale and oil shale semicoke are $\mathrm{SiO}_{2}, \mathrm{Al}_{2} \mathrm{O}_{3}, \mathrm{CaO}$, and $\mathrm{Fe}_{2} \mathrm{O}_{3}$, which can be successfully utilized in the pozzolanic reaction $[17,18]$. Oil shale ash is a byproduct after oil shale or oil shale semicoke combustion. To use the pozzolanic characteristics of oil shale, some scholars studied on the performance of oil shale ash as binder and filler materials of road construction. For instance, Raado et al. [19] used oil shale ash as the main binder for low strength concrete. The laboratory results showed that the water resistance was improved and 
expansion diminished with proper oil shale ash content in the concrete. Al-Massaid et al. [20] studied the use of oil shale ash as a partial substitute for the asphalt binder in bituminous paving mixtures under normal conditions as well as under freezing and thawing conditions. The test results indicated that the substitution of ash up to 10 percent by volume of asphalt would improve the performance of mixtures under both conditions. It follows that the chemical composition of oil shale ash is partly active. However, no attempt has been made to evaluate the practicability of oil shale semicoke as a road construction aggregate. Through the preliminary investigation, we found that oil shale semicoke of Jilin province is in good integrity of rock and has a certain strength. Meanwhile, oil shale semicoke in the landfill site has a relatively continuous gradation. These characteristics have certain similarity to graded crushed gravel. On the other hand, the active ingredient in semicoke may be beneficial for the pozzolanic reaction with cement. These allow semicoke to have potential applications as aggregate of cement-stabilized road base or subbase course construction, and oil shale semicoke would be utilized in large quantities. Therefore, the problems caused by accumulation of oil shale semicoke can be solved significantly. Furthermore, the environmentally friendly target, saving natural gravel resource, and resource utilization of oil shale semicoke could be achieved. In this connection, researchers have investigated the practicability of cement-stabilized oil shale semicoke as a road base or subbase course construction material.

In recent decades, many researches have been done on using different kinds of industrial waste residue instead of sand or gravel to prepare the pavement base materials, which provide valuable preferences for the research on performance of oil shale semicoke acting as a base course material in this paper. In the Netherlands, blast furnace slags are used as a self-cementing road base material on a wide scale for many decades [21]. Singh et al. [22] carried out investigations on cement-stabilized fly ash-granulated blast furnace slag mixes in order to evaluate its performance for road embankments and for base and subbase courses of highway pavements. They confirmed its suitability for use in base and subbase courses in highway pavements with proper combinations of raw materials. Sharma and Sivapullaiah [23] investigated the effect of the joint activation of fly ash- and ground-granulated blast furnace slag on the unconfined compressive strength of mixtures of these two materials. This study suggested that properly designed combinations of fly ash-slag-lime can be used as construction materials for infrastructure projects such as structural fills or subgrade and subbase courses in pavements without requiring large quantities of lime. Based on experiment study in gangue base course mixture materials for pavement, Wang et al. [24] concluded that coal gangue, acting as the solid skeleton of pavement base materials, can efficiently reduce the drying shrinkage. Additionally, similar to fly ash in mixture material, gangue can react with lime (so called pozzolanic reaction), resulting in the formation of a certain strength, good water stability, and frost resistance, which is good overall for the pavement base. Similarly, additional strength may be provided, utilizing oil shale semicoke as the solid skeleton of base course materials, because of the pozzolanic characteristics in oil shale semicoke. Zhang et al. [25] conducted test research on temperature shrinkage performance of cement-stabilized coal gangue base course materials. Analysis of test results shows that cement cinderstabilized coal gangue base course materials have less temperature shrinkage coefficient, which are propitious to pavement base course in cold areas. Cheng and Zhang [26] studied anticracking performance of cement-stabilized coal gangue. To have both road performance and anticracking performance, researchers recommended that reasonable proportion of cement in cement-stabilized coal gangue is five percent to six percent. Pasetto et al. [27, 28] carried out experimental evaluation of high-performance base course and road base asphalt concrete with electric arc furnace steel (EAF) slags. The mixtures with EAF slags presented better mechanical characteristics than those of corresponding asphalts with natural aggregate, and the test result of rheological characterization indicated that the environmental sustainability of modified asphalt concrete with EAF slags can be further enhanced. Androjić and Dimter [29] conducted compressive strength testing on stabilisation mixes with steel furnace slag to check whether slag can be used as aggregate in pavement base courses and confirmed that slag can be used in stabilized base courses of pavement structures. Zhang and Ren [30] studied strength and thermal conductive characteristics of cement-stabilized cinder base and concluded that cinder content should be in 35\% 40\% to have both strength and thermal conductivity of fillings. Liu et al. [31] investigated the pavement performance of cementstabilized municipal solid waste incineration bottom ash aggregate (BAA) and crushed stones. Based on the performance analysis, it is recommended that the dosage of BAA is $20 \%$ to $30 \%$. Qin et al. [32] evaluated the corrosion resistance of manganese slag cement-stabilized macadam base. It was observed that corrosion resistance and scour resistance performances were significantly improved with the incorporation of manganese.

In this paper, the properties of raw materials were first studied. Then, the performances of cement-stabilized oil shale semicoke were tested, including compaction characteristic, unconfined compressive strength, splitting strength, compressive modulus of resilience, and frost resistance. Two types of aggregate gradation structures, suspend-dense structure (SDS) and framework-dense structure (FDS), were used throughout the tests to study and compare the performances. Finally, the suitability of oil shale semicoke as a road base or subbase course construction material was discussed.

\section{Background}

In China, abandoned oil shale semicoke landfill occupies a large number of forest land and farmland owing to the absence of efficient disposal techniques, as shown in Figure 1. In order to alleviate the environmental and land occupation pressure of oil shale semicoke landfill, oil shale retorting plants need to afford a great deal of extra cost every 


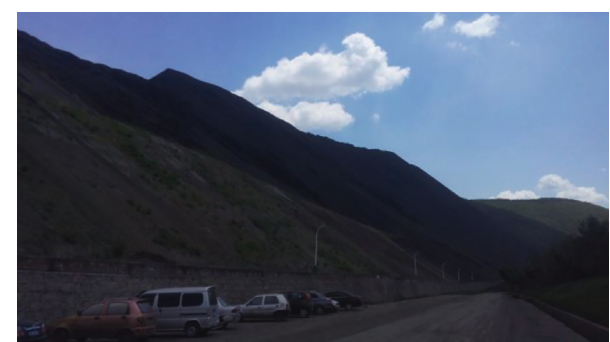

Figure 1: A landfill site of abandoned oil shale semicoke in Jilin province of China.

year. Therefore, a method of disposing large amount of oil shale semicoke is of great significance to environmental protection and ecological sustainability.

Semirigid base has been widely used in high-grade asphalt pavement in China for decades. Semirigid pavement is composed of asphalt pavement, semirigid base, semirigid subbase, and soil base, whose main bearing layer is semirigid base and auxiliary bearing layer is semirigid subbase. Semirigid base or semirigid subbase is usually composed of cement or lime, fly ash, and other inorganic binders mixed with gravel or graded industrial waste aggregate, whose rigidity is between flexible base and rigid base. In the early curing period, semirigid base shows a mechanical property approximated to the flexible base course, while its strength and stiffness increase greatly in the later curing period. Therefore, the mechanical property of semirigid base especially caters to performance requirements of asphalt pavement. Figure 2 gives the typical semirigid pavement structure in China.

Preliminary investigation results show that oil shale semicoke in Jilin province is in good integrity of rock and has a certain strength. Combining with the pozzolanic characteristics of oil shale, there is a potential possibility that graded oil shale semicoke can replace gravel as a road base or subbase course construction material. In terms of above analysis, the suitability of oil shale semicoke acting as the solid skeleton of cement-stabilized pavement base materials was studied. A series of laboratory tests were conducted to investigate the performance of cement-stabilized oil shale semicoke mixture in this paper.

\section{Raw Materials}

The oil shale semicoke used in this investigation was collected from processing plant in Wangqing County of Jilin province; its appearance is shown in Figure 3. The oil shale semicoke was sieved to different grain size ranges, including coarse aggregates ranging from $5 \mathrm{~mm}$ to $31.5 \mathrm{~mm}$ and fine aggregates smaller than $5 \mathrm{~mm}$, to prepare the mixture.

A scanning electron microscope (SEM) was used to investigate the microsurface characteristics of oil shale semicoke. Then, X-ray photoelectron spectroscopy (XPS) and X-ray fluorescence spectrometry (XRF) were used to test and analyze the elemental and chemical compositions of oil shale semicoke. The result of SEM is shown in Figure 4.

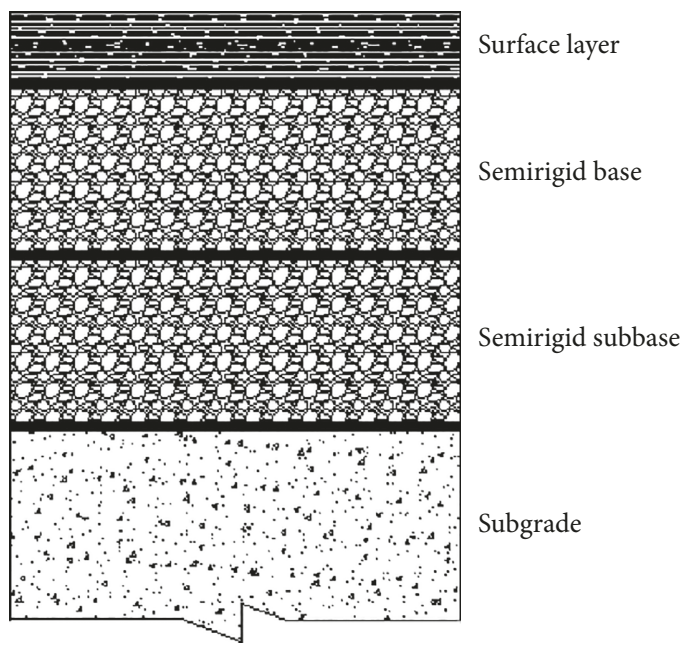

FIGURE 2: Typical semirigid asphalt pavement structure in China.

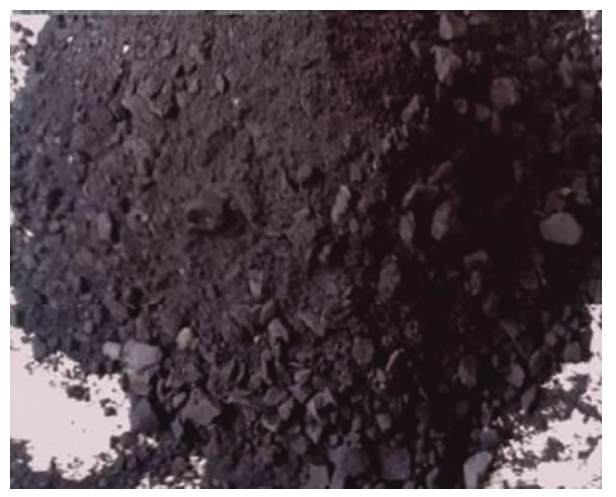

Figure 3: Appearance of oil shale semicoke used in this paper.

According to Figure 4, it can be seen that the surface of oil shale semicoke is rough, and it is densely embedded on the surface by irregular granular and flaky structure. The oil shale semicoke is featured in dense structures, and there are only some irregular pores.

Elemental composition of oil shale semicoke was studied by XPS. The XPS is illustrated in Figure 5, and the result of elemental composition analysis is shown in Table 1.

The chemical composition of oil shale semicoke was determined by XRF. Table 2 gives the test result.

As shown in Table 2, the main chemical compositions of oil shale semicoke are $\mathrm{SiO}_{2}, \mathrm{Al}_{2} \mathrm{O}_{3}, \mathrm{CaO}$, and $\mathrm{Fe}_{2} \mathrm{O}_{3}$, whose active parts probably can be utilized in the pozzolanic reaction, forming an extracertain strength.

The physical properties of oil shale semicoke, including apparent density, gross volume density, water absorption, crushing value, and free expansion rate, were tested as per the Chinese specification of JTG E42-2005 [33]. All oil shale semicoke materials needed for tests should be selected from the stack by using the sample quartering method, and the indoor temperature should be controlled around $25^{\circ} \mathrm{C}$. These physical properties of oil shale semicoke were tested at least twice, and Table 3 shows the averages of the test results. 

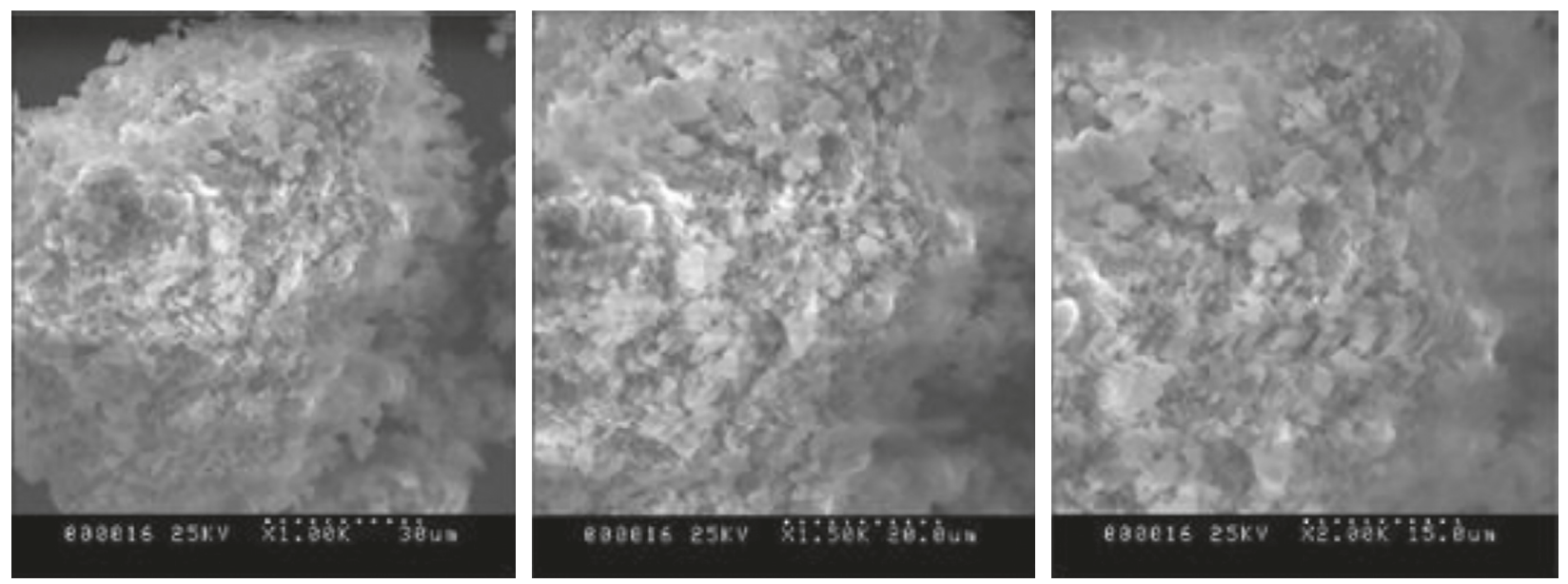

FIgure 4: The result of SEM.

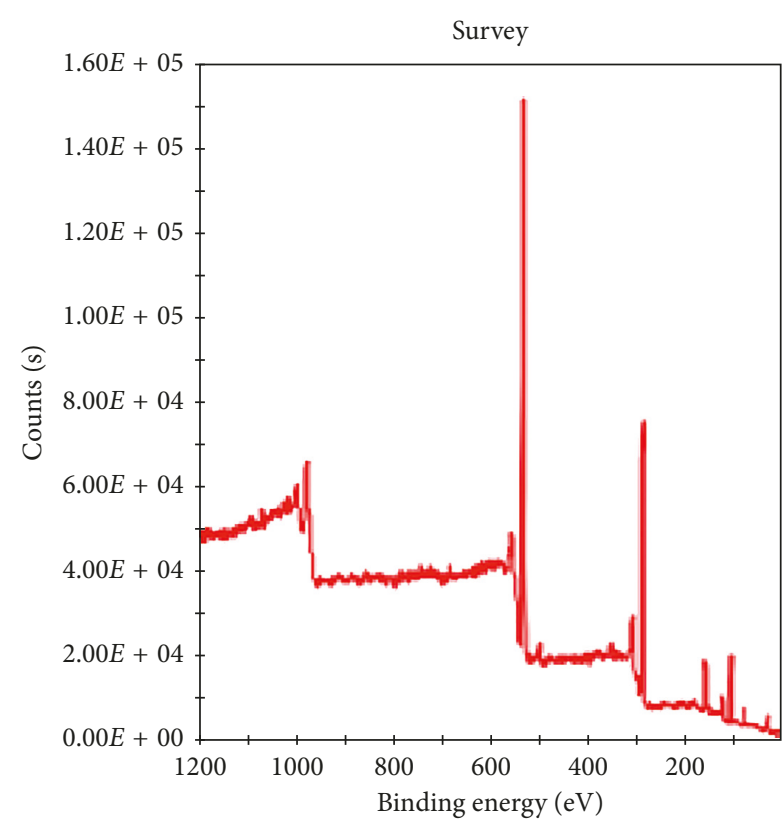

FIGURE 5: XPS of oil shale semicoke.

As shown in Table 3, oil shale semicoke has smaller density, higher porosity, higher water absorption, and lower strength than natural gravel, which means lower strength and stiffness than natural gravel. Therefore, it is not recommended to use oil shale semicoke as a load-bearing aggregate of heavy traffic road construction material.

The ordinary Portland cement of grade 32.5 was procured from Jilin Yatai Dinglu Cement Ltd., and its performance was tested using the method of Chinese specification GB 175 [34]. All testing instruments should be checked to comply with the specification. Laboratory temperature is $20 \pm 2^{\circ} \mathrm{C}$ and the relative humidity should not be less than $50 \%$, while the controlled chamber temperature is $20 \pm 1^{\circ} \mathrm{C}$ and the relative humidity should not be less than $90 \%$. In compressive strength and flexural strength test, the water-binder ratio should be 0.50 and the fluidity of cement mortar is not less than $180 \mathrm{~mm}$. The results are shown in Table 4 .

\section{Preparation of Specimens}

Suspend-dense structure (SDS) and framework-dense structure (FDS) were selected as the gradation structure types of oil shale semicoke aggregate in this paper. SDS and FDS are the two most commonly used gradation structure types of semirigid base or semirigid subbase in China. As shown in Figure 6, FDS contains more coarse aggregates than SDS. That is, the structure model of FDS is fine aggregates filling the skeleton formed by the extrusion of the coarse aggregates, while the structure model of SDS is coarse aggregates distributing in very dense fine aggregates. The two gradation structure types were designed as per Chinese specification JTG D50 [35], which gives a detailed introduction to design standards of Chinese highway asphalt pavement. The gradations and gradation curves of SDS and FDS in this paper are shown in Table 5 and Figure 7, respectively.

To simulate the engineering practice of highway base course construction in China, considering that the density of oil shale semicoke is less than natural gravel, cement contents of SDS and FDS mixes of cement-stabilized oil shale semicoke are both $7 \%$ in this paper. The Chinese specification JTG E51 [36] introduces road performance test methods of cement stabilized materials, which is the main reference of this paper.

The moisture contents versus dry density relationships for SDS and FDS mixes of cement-stabilized oil shale semicoke were determined by using the modified compaction test as per Chinese specification JTG E51 [36]. Model LD-140 electric compaction device was used in this paper as shown in Figure 8. According to the dry density and moisture content relationship, as shown in Figure 9, the optimum moisture content (OMC) and maximum dry density (MDD) were calculated. The OMC and MDD are summarized in Table 6.

According to Chinese specification JTG E51 [36], cylinder specimens of SDS and FDS were prepared at their respective OMC and MDD by applying static compressive force in a constant volume sampler. The compacted specimens were $150 \mathrm{~mm}$ in diameter and $150 \mathrm{~mm}$ in height. All of the samples were cured in a temperature and humidity 
TABLE 1: Elemental composition of oil shale semicoke.

\begin{tabular}{lcccccccccccc}
\hline Elementals & $\mathrm{C}$ & $\mathrm{N}$ & $\mathrm{Mg}$ & $\mathrm{Al}$ & $\mathrm{S}$ & $\mathrm{Si}$ & $\mathrm{Na}$ & $\mathrm{Ca}$ & $\mathrm{Fe}$ & $\mathrm{O}$ & $\mathrm{K}$ \\
\hline Contents (\%) & 46.51 & 0.72 & 2.46 & 3.52 & 0.13 & 10.29 & 0.40 & 0.65 & 0.52 & 34.59 & 0.22 \\
\hline
\end{tabular}

TABLE 2: The chemical composition of oil shale semicoke.

\begin{tabular}{lcccccccccc}
\hline Chemical composition & $\mathrm{SiO}_{2}$ & $\mathrm{Al}_{2} \mathrm{O}_{3}$ & $\mathrm{CaO}$ & $\mathrm{Fe}_{2} \mathrm{O}_{3}$ & $\mathrm{Na}_{2} \mathrm{O}$ & $\mathrm{K}_{2} \mathrm{O}$ & $\mathrm{MgO}$ & $\mathrm{TiO}_{2}$ & $\mathrm{P}_{2} \mathrm{O}_{5}$ & $\mathrm{MnO}$ \\
\hline Contents (\%) & 54.57 & 14.63 & 6.13 & 5.95 & 3.65 & 2.98 & 2.67 & 0.70 & 0.49 & 0.10 \\
\hline
\end{tabular}

TABLE 3: The physical properties of oil shale semicoke.

\begin{tabular}{lcccc}
\hline Apparent density $\left(\mathrm{g} / \mathrm{cm}^{3}\right)$ & Gross volume density $\left(\mathrm{g} / \mathrm{cm}^{3}\right)$ & Water absorption $(\%)$ & Crushing value (\%) & Free expansion rate (\%) \\
\hline 2.567 & 1.614 & 20.5 & 48.7 & 3.75 \\
\hline
\end{tabular}

TABLE 4: Experimental results of cement.

\begin{tabular}{|c|c|c|c|c|c|c|c|}
\hline \multirow[t]{2}{*}{$\begin{array}{l}\text { Normal } \\
\text { consistency (\%) }\end{array}$} & \multicolumn{2}{|c|}{ Setting time $(\min )$} & \multirow[t]{2}{*}{$\begin{array}{c}\text { Surface area ratio } \\
\text { (Blaine method) }\left(\mathrm{m}^{2} / \mathrm{kg}\right)\end{array}$} & \multicolumn{2}{|c|}{$\begin{array}{l}\text { Compressive } \\
\text { strength } \\
(\mathrm{MPa})\end{array}$} & \multicolumn{2}{|c|}{$\begin{array}{c}\text { Flexural } \\
\text { strength } \\
(\mathrm{MPa})\end{array}$} \\
\hline & Initial setting time & Final setting time & & $3 \mathrm{~d}$ & $28 \mathrm{~d}$ & $3 \mathrm{~d}$ & $28 \mathrm{~d}$ \\
\hline 25.0 & 255 & 328 & 358 & 12.9 & 37.4 & 3.7 & 7.0 \\
\hline
\end{tabular}

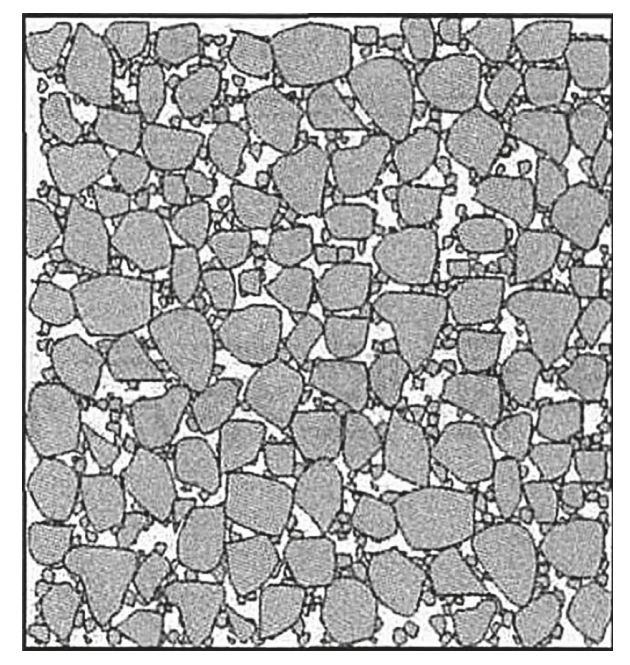

(a)

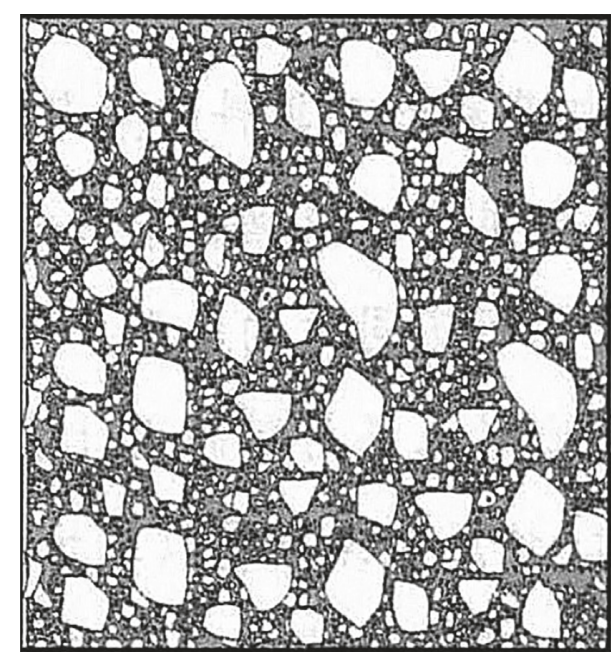

(b)

FIGURE 6: Gradation structure models: (a) structure model of FDS and (b) structure model of SDS.

TABLE 5: The gradations of SDS and FDS.

Diameter $(\mathrm{mm})$

Passing ratio of SDS (\%)

Passing ratio of FDS (\%)

$\begin{array}{lcccc}37.5 & 31.5 & 26.5 & 19 & 9.5 \\ 100 & 100 & 97 & 90 & 63 \\ 100 & 100 & 97.5 & 75 & 45\end{array}$

4.75
40
30

2.36
25
22

\begin{tabular}{cc}
0.6 & 0.075 \\
12 & 3 \\
10 & 1.5 \\
\hline
\end{tabular}

controlled chamber (curing temperature $=20^{\circ} \mathrm{C} \pm 2^{\circ} \mathrm{C}$; curing relative humidity $>95 \%$ ) for 7,28 , and 90 days. The cylinder specimens were used for the tests on the UCS, STS, $\mathrm{CRM}$, and frost resistance performance.

\section{Methodology}

5.1. Experiments. In this paper, the engineering properties of cement-stabilized oil shale semicoke were evaluated.
Laboratory tests such as unconfined compressive strength (UCS) test, splitting tensile strength (STS) test, compressive resilient modulus (CRM) test, and freezing-thawing test were conducted. The cured specimens of SDS and FDS mixes were prepared as per the specific test requirements. The experiments were divided into 12 test groups, as shown in Table 7. In order to make the test results more representative, each test group consisted of 13 repeated samples, and the test results were processed with statistical methods. 


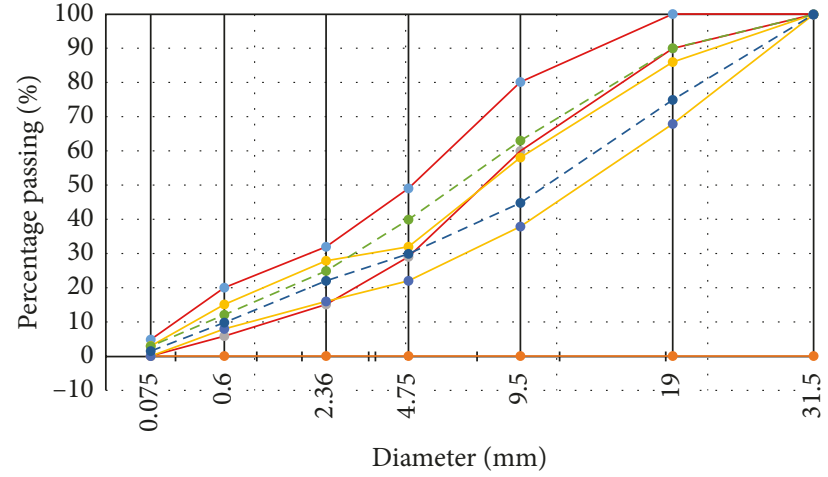

$\begin{array}{ll}\rightarrow \text { Upper limit of SDS } & - \text { Lower limit of FDS } \\ \rightarrow-\text { Lower limit of SDS } & -- \text { SDS } \\ \rightarrow-\text { Upper limit of FDS } & -- \text { FDS }\end{array}$

FIGURE 7: Gradation curves of SDS and FDS.

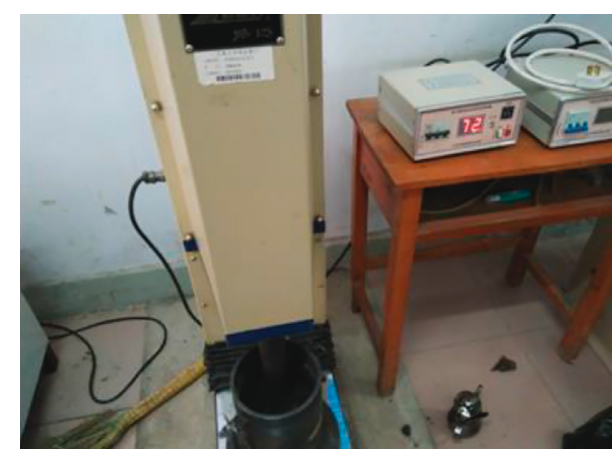

FIgURE 8: Compaction test.

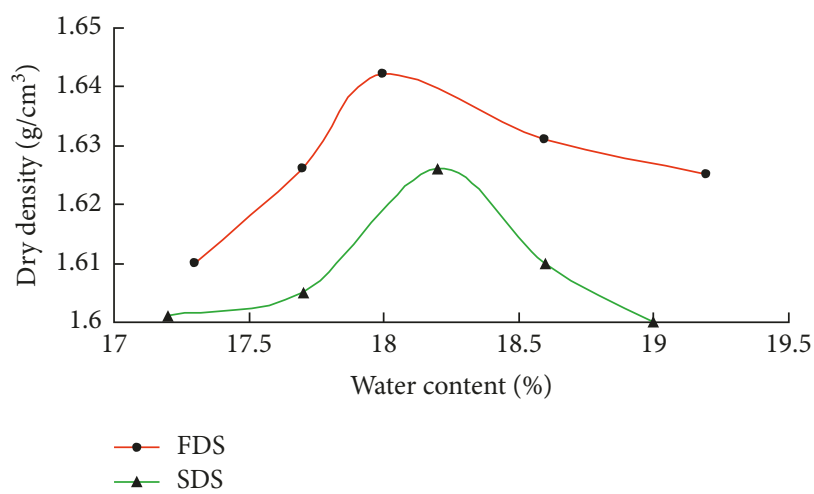

FIgUre 9: Moisture-density curves of SDS and FDS.

TABLE 6: The OMC and MDD of SDS and FDS.

\begin{tabular}{lcc}
\hline & OMC $(\%)$ & MDD $\left(\mathrm{g} / \mathrm{cm}^{3}\right)$ \\
\hline FDS & 18.0 & 1.642 \\
SDS & 18.2 & 1.626 \\
\hline
\end{tabular}

5.1.1. Unconfined Compressive Strength Test. UCS is the basic technical index of a base course material. It reflects the ability of the base structure to bear load, which is determined by the coarse aggregate extrusion structure, effect of fine aggregate filling, and bond strength of binder. UCS of SDS
TABLE 7: The experimental programme.

\begin{tabular}{lccc}
\hline Number & Cement (\%) & $\begin{array}{c}\text { Aggregate gradation } \\
\text { structure }\end{array}$ & Test \\
\hline 1 & 7 & FDS & UCS (7 d) \\
2 & 7 & SDS & UCS (7 d) \\
3 & 7 & FDS & UCS (28 d) \\
4 & 7 & SDS & UCS (28 d) \\
5 & 7 & FDS & UCS (90 d) \\
6 & 7 & SDS & UCS (90 d) \\
7 & 7 & FDS & STS (90 d) \\
8 & 7 & SDS & STS (90 d) \\
9 & 7 & FDS & CRM (90 d) \\
10 & 7 & SDS & CRM (90 d) \\
11 & 7 & FDS & Freezing-thawing \\
12 & 7 & SDS & Freezing-thawing \\
\hline
\end{tabular}

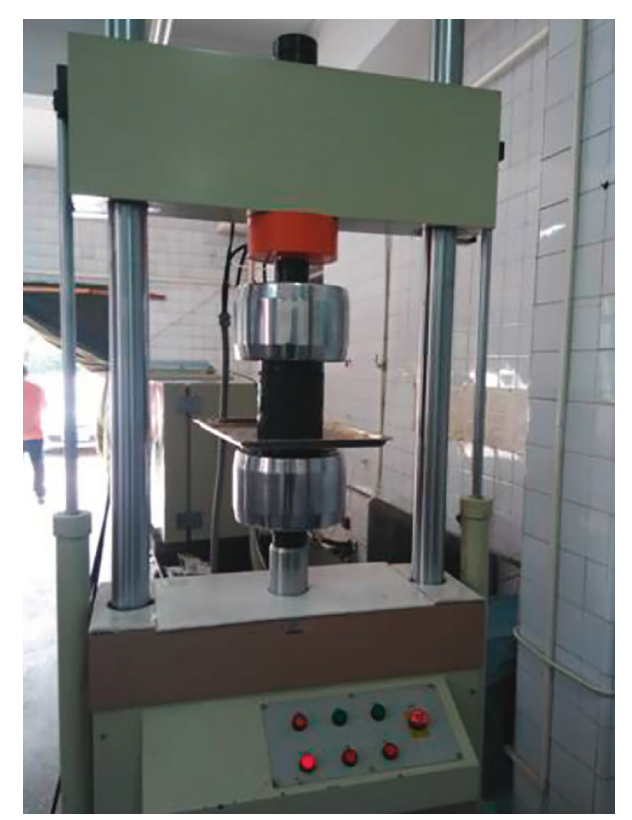

Figure 10: Unconfined compressive strength test.

and FDS mixes of cement-stabilized oil shale semicoke was determined as per Chinese specification JTG E51 [36]. As shown in Figure 10, the mechanical testing and simulation (MTS) device was adopted to test the UCS of cured samples, using the strain-control condition at an axial strain rate of $1 \mathrm{~mm} / \mathrm{min}$. UCS of samples is calculated using

$$
R_{\mathrm{c}}=\frac{P}{A}
$$

where $R_{c}$ is the UCS of one sample (MPa), $P$ is the maximum loading leading to sample failure $(\mathrm{N})$, and $A$ is the sectional area of one sample $\left(\mathrm{mm}^{2}\right)$. Then, the UCS values at curing times of 7, 28, and 90 days were determined.

5.1.2. Splitting Tensile Strength Test. In the STS test, the sample is subjected to the tangential tensile stress and radial compressive stress at the same time, and its stress state is closer to the stress state of actual pavement structure than the direct uniaxial tension. Therefore, STS can reflect the 


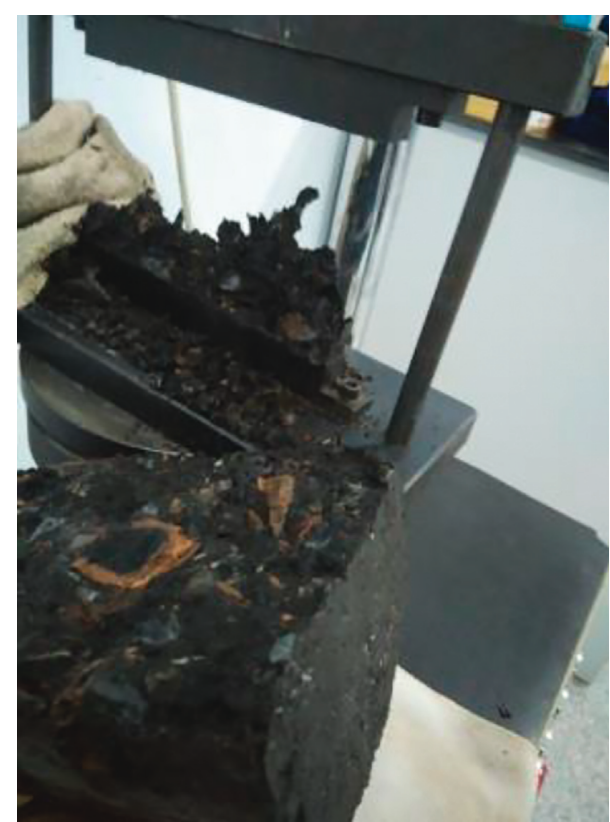

Figure 11: Splitting tensile strength test.

tensile capacity of the base course material, which is mainly determined by the bond strength of the binder. The STS tests were conducted according to Chinese specification JTG E51T0855-2009 [36]. The samples were cured for 90 days. As shown in Figure 11, the tests were conducted using an aligning jig to apply a force along the longitudinal side of the samples, with an axial strain rate of $1 \mathrm{~mm} / \mathrm{min}$. The STS is calculated out by

$$
R_{i}=\frac{0.004178 P}{H}
$$

where $R_{i}$ is the STS of one sample (MPa), $P$ is the maximum loading leading to sample failure $(\mathrm{N})$, and $H$ is the height of the sample $(\mathrm{mm})$.

5.1.3. Compressive Resilient Modulus Test. The CRM test is used to study the stiffness performance of the base course structure, reflecting the compressive strength and the ability to resist vertical deformation of the base course material. The CRM tests were conducted in accordance with Chinese specification JTG E51 [36]. The samples were cured for 90 days. As shown in Figure 12, the mechanical testing and simulation (MTS) device was used to apply a pressure to samples at a loading rate of $1 \mathrm{~mm} / \mathrm{min}$. The maximum applied loading is about $70 \%$ of UCS and divided into six progressively loading. The loading gradually increased from a low load to a high load; the deformations of each loading level were recorded. The compressive resilient modulus is calculated using

$$
E_{\mathrm{c}}=\frac{P H}{L}
$$

where $E_{\mathrm{c}}$ is the compressive resilient modulus (MPa), $P$ is the progressively pressure $(\mathrm{MPa}), H$ is the height of the sample $(\mathrm{mm})$, and $L$ is the resilient deformation $(\mathrm{mm})$.

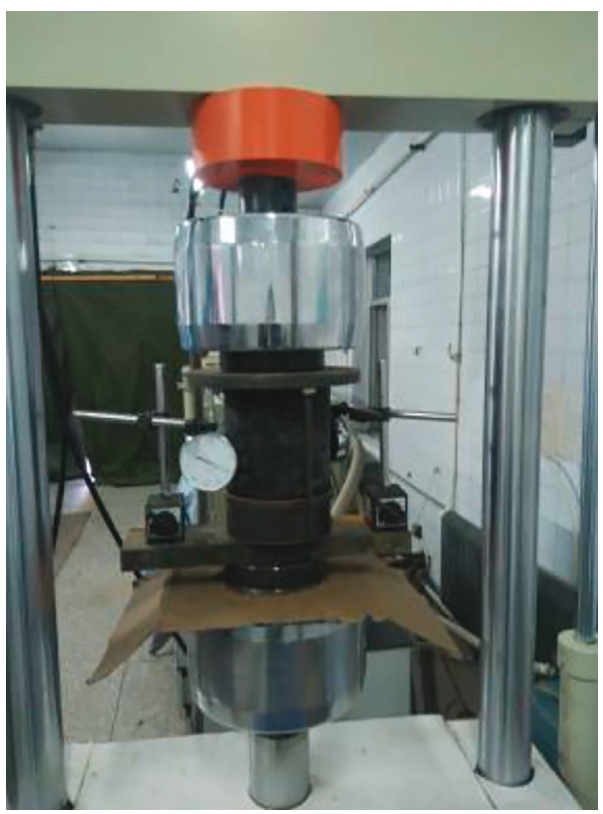

Figure 12: Compressive resilient modulus test.

5.1.4. Freezing-Thawing Test. The freezing-thawing test was conducted to evaluate the ability of frost resistance and fatigue resistance of the road base course structure. The frost resistance was tested according to Chinese specification JTG E51 [36]. The frost resistance of samples after 28 days of curing was evaluated by the loss ratio of UCS after 5 freezethaw cycles of samples. The samples of cement-stabilized oil shale semicoke mixes were exposed to 5 freeze-thaw cycles consisting of freezing for $16 \mathrm{~h}$ in a temperature controlled chamber of $-18 \pm 1^{\circ} \mathrm{C}$ and thawing for $8 \mathrm{~h}$ in water of $+20 \pm$ $1^{\circ} \mathrm{C}$. Figure 13 gives the samples' appearance change of two gradation structure types, that is, SDS and FDS, during the freezing-thawing test. The frost resistance index is finally given by

$$
\mathrm{BDR}=\frac{100 R_{\mathrm{DC}}}{R_{\mathrm{c}}},
$$

where BDR, the frost resistance index, is the loss ratio of UCS of the sample after 5 freeze-thaw cycles (\%), $R_{\mathrm{DC}}$ is the UCS after 5 freeze-thaw cycles $(\mathrm{MPa})$, and $R_{\mathrm{c}}$ is the UCS of the reference sample not subjected to any freeze-thaw cycles $(\mathrm{MPa})$.

\section{Results and Discussion}

6.1. Unconfined Compressive Strength. The UCS test results of samples with different gradation structure types and curing times are shown in Table 8. According to Chinese specification JTG E51 [36], the strength representative values in Table 8 can be used in the strength performance evaluation of cement-stabilized oil shale semicoke. The UCS at 7 days of cement-stabilized materials should comply with the requirements of Chinese specification JTG/T F20 [37], which rules the UCS standard at 7 days for cement-stabilized materials, as shown in Table 9. It is observed that the UCSs at 


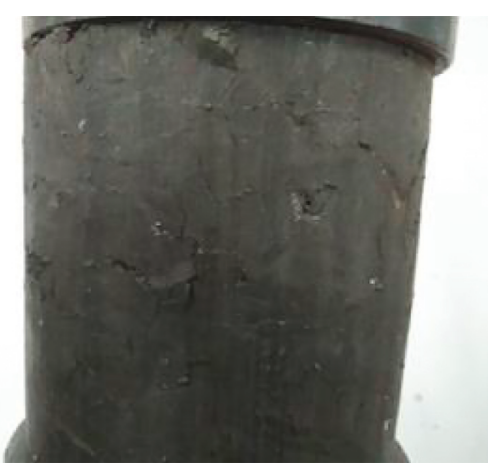

(a)

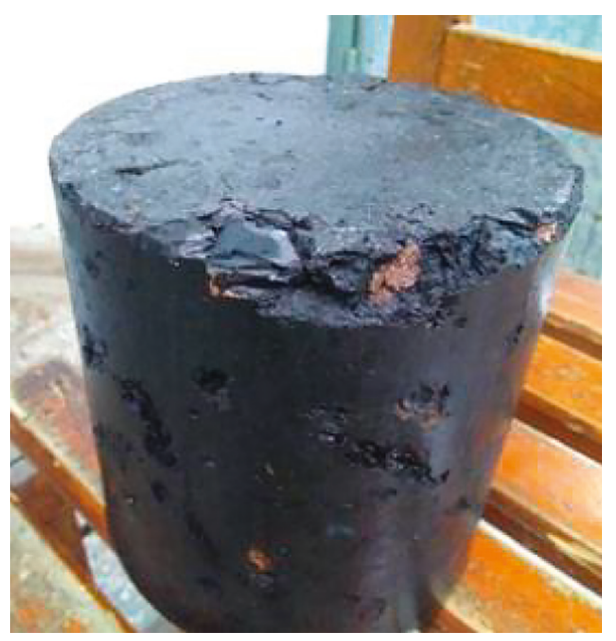

(c)

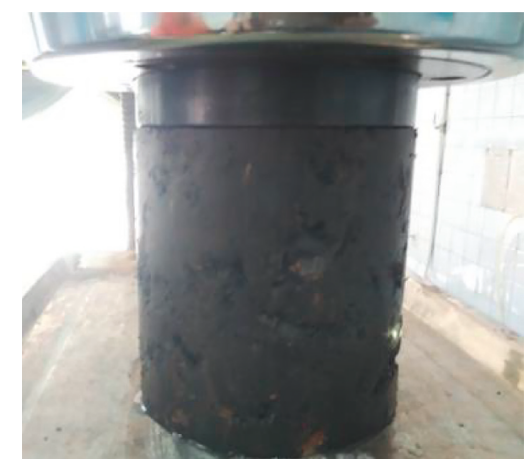

(b)

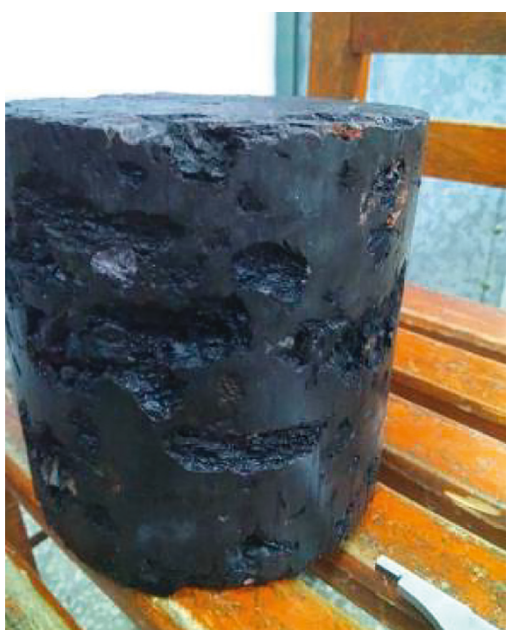

(d)

FIGURE 13: Freezing-thawing test: (a) appearance of SDS before freeze-thaw cycle, (b) appearance of FDS before freeze-thaw cycle, (c) appearance of SDS after 5 freeze-thaw cycles, and (d) appearance of FDS after 5 freeze-thaw cycles.

TABLE 8: UCS test results.

\begin{tabular}{lccccccc}
\hline $\begin{array}{l}\text { Curing } \\
\text { times (days) }\end{array}$ & $\begin{array}{c}\text { Gradation } \\
\text { structure types }\end{array}$ & $\begin{array}{c}\text { Minimum strength } \\
\text { value (MPa) }\end{array}$ & $\begin{array}{c}\text { Maximum strength } \\
\text { value (MPa) }\end{array}$ & $\begin{array}{c}\text { Mean } \\
\text { value (MPa) }\end{array}$ & $\begin{array}{c}\text { Standard } \\
\text { deviation }\end{array}$ & $\begin{array}{c}\text { Coefficient variation (\%) } \\
\text { valuength representative }\end{array}$ & $\begin{array}{c}\text { Strenge } \\
\text { value (MPa) }\end{array}$ \\
\hline \multirow{2}{*}{7} & FDS & 3.98 & 5.01 & 4.51 & 0.291 & 6.45 & 4.03 \\
& SDS & 4.01 & 4.85 & 4.39 & 0.306 & 6.97 & 3.89 \\
\hline \multirow{2}{*}{28} & FDS & 5.01 & 6.24 & 5.36 & 0.385 & 7.17 & 7.73 \\
& SDS & 6.19 & 7.71 & 6.75 & 0.507 & 7.51 & 7.92 \\
\hline \multirow{2}{*}{90} & FDS & 5.82 & 6.31 & 6.11 & 0.472 & 7.21 & 7.33 \\
& SDS & 7.18 & 7.88 & 7.49 & 0.503 & 7.60 & 6.66 \\
\hline
\end{tabular}

TABLE 9: UCS standard at 7 days for cement-stabilized materials.

\begin{tabular}{lcccc}
\hline Structure layers & Highway grade & Very heavy traffic (MPa) & Heavy traffic (MPa) & Medium and light traffic (MPa) \\
\hline \multirow{2}{*}{ Base course } & Freeway, class 1 highway & $5.0-7.0$ & $4.0-6.0$ & $3.0-5.0$ \\
& Class 2 and below highway & $4.0-6.0$ & $3.0-5.0$ & $2.0-4.0$ \\
\hline \multirow{2}{*}{ Subbase course } & Freeway, class 1 highway & $2.5-4.5$ & $2.5-4.5$ & $2.0-4.0$ \\
& Class 2 and below highway & $2.0-4.0$ & $2.0-4.0$ & $1.0-3.0$ \\
\hline
\end{tabular}

7 days of cement-stabilized oil shale semicoke with two gradation structure types, SDS and FDS, are both greater than $3.5 \mathrm{MPa}$, which meets the subbase requirements of all highway grades and traffic grades and the base requirements of highway with lower grade or lighter traffic.
UCS of cement-stabilized oil shale semicoke grows with the increase of curing time. Figure 14 gives the trends of strength growth for two gradation structure types with curing time.

From Figure 14, UCS of cement-stabilized oil shale semicoke increases with increasing curing time. The UCS 


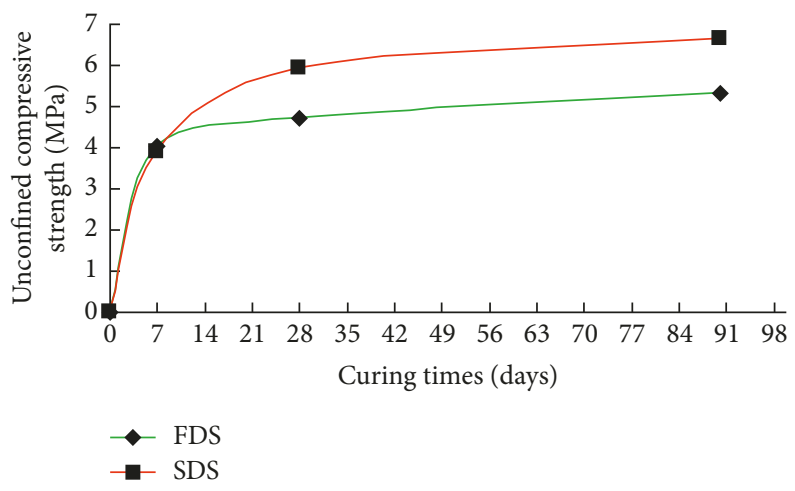

FIGURE 14: UCS of FDS and SDS growing with curing time.

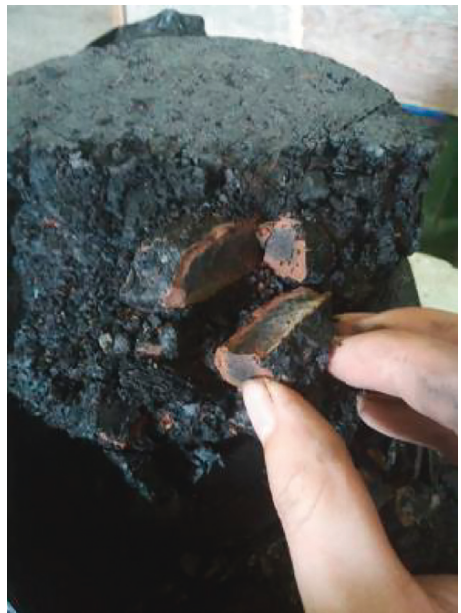

(a)

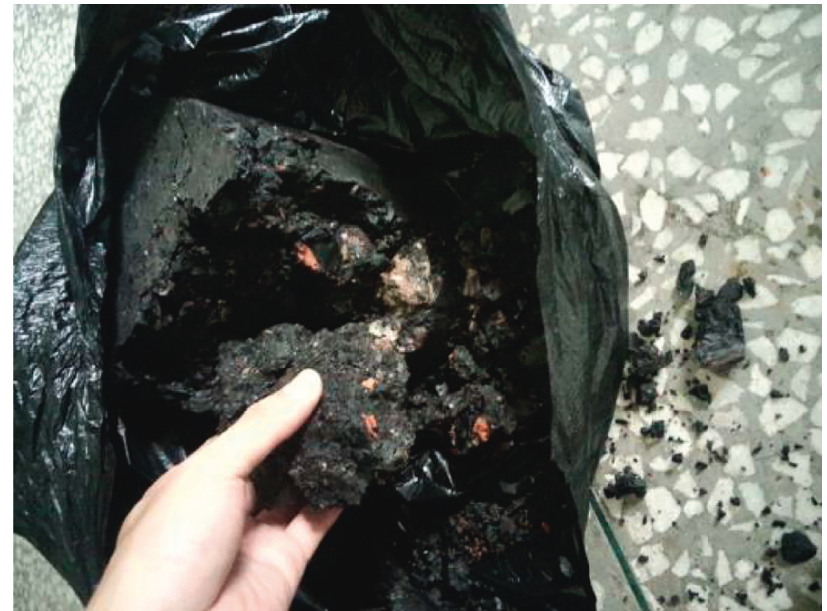

(b)

FIgURE 15: The internal cracking surfaces of samples: (a) FDS and (b) SDS.

results at 7 days of FDS and SDS are similar, whereas the strength growth of SDS at 28 days is significantly higher than that of FDS. From then on, the strength growth trends of the two gradation structure types are similar until the 90 days. It's obvious that the strength growth difference of the two gradation structure types mainly occurs during the period from 7 days to 28 days. The mixture structure is composed of aggregate, fine material filling, and cement bonding, whose strength is mainly determined by the strength of aggregate itself and the bond strength of hydration of cement. During the 7 days of curing time, the bond strength of cement is initially formed, which is smaller than the strength of aggregate itself and the UCS is mainly determined by the bond strength of cement. Therefore, the UCS results at 7 days of FDS and SDS are similar because of the same cement content. During the period from 7 days to 28 days, the bond strength of cement increases significantly. Considering that the crushing value of oil shale semicoke aggregate is larger than natural gravel, the strength of the sample is largely determined by the crushing of the aggregate. FDS mixture contains more coarse aggregate than SDS mixture, which means that the FDS sample is easier to be crushed than SDS, showing smaller UCS than SDS.
The crushed samples at 28 days of two gradation structure types were artificially cracked, as shown in Figure 15. Comparing the internal cracking surfaces of the two samples, it can be seen that FDS appeared to be an obvious phenomenon of locally crushed coarse aggregate leading to failure. Analyzing the gradation difference of FDS and SDS, SDS has more $2.36 \mathrm{~mm}-9.5 \mathrm{~mm}$ aggregate content, less $19 \mathrm{~mm}-31.5 \mathrm{~mm}$ aggregate content than FDS, which means less influence from framework aggregate crushing of oil shale semicoke on the sample failure than FDS. Secondly, gradation of SDS makes the mix graded better than FDS, thus increasing the compacted density and hence the mechanical strength of the compacted mixture. There is also an appreciable gain in strength with addition of fine oil shale semicoke at constant cement content, because fine oil shale semicoke contains reactive $\mathrm{SiO}_{2}, \mathrm{Al}_{2} \mathrm{O}_{3}, \mathrm{CaO}$, and $\mathrm{Fe}_{2} \mathrm{O}_{3}$, which can be effectively utilized in the pozzolanic reaction with cement.

6.2. Splitting Tensile Strength. Table 10 shows the STS test results of SDS and FDS at curing time of 90 days.

As shown in Table 10, the STS of FDS is $0.46 \mathrm{MPa}$, while the STS of SDS is $0.65 \mathrm{MPa}$, indicating that the aggregate 
TABLE 10: The test results of STS.

\begin{tabular}{lcccccc}
\hline & $\begin{array}{c}\text { Minimum strength } \\
\text { value }(\mathrm{MPa})\end{array}$ & $\begin{array}{c}\text { Maximum strength } \\
\text { value }(\mathrm{MPa})\end{array}$ & $\begin{array}{c}\text { Mean value } \\
(\mathrm{MPa})\end{array}$ & $\begin{array}{c}\text { Standard } \\
\text { deviation }\end{array}$ & $\begin{array}{c}\text { Coefficient } \\
\text { variation }(\%)\end{array}$ & $\begin{array}{c}\text { Strength representative } \\
\text { value }(\mathrm{MPa})\end{array}$ \\
\hline FDS & 0.48 & 0.68 & 0.59 & 0.080 & 13.57 & 0.46 \\
SDS & 0.64 & 0.75 & 0.71 & 0.035 & 4.99 & 0.65 \\
\hline
\end{tabular}

TABLE 11: The test results of CRM.

\begin{tabular}{ccc}
\hline & $\begin{array}{c}\text { Progressively } \\
\text { load }(\mathrm{kN})\end{array}$ & $\begin{array}{c}\text { Mean value of the resilient } \\
\text { deformation }(\mathrm{mm})\end{array}$ \\
\hline \multirow{4}{*}{ FDS } & 10 & 0.324 \\
& 20 & 0.401 \\
& 30 & 0.460 \\
& 40 & 0.527 \\
& 50 & 0.574 \\
& 60 & 0.660 \\
\hline \multirow{4}{*}{ SDS } & 10 & 0.320 \\
& 20 & 0.406 \\
& 30 & 0.475 \\
& 40 & 0.525 \\
& 50 & 0.589 \\
& 60 & 0.658
\end{tabular}

structure has obvious influence on the tensile strength of mixtures, and SDS exhibits better tensile properties. In addition, the coefficient variation of FDS is $13.57 \%$, while the coefficient variation of SDS is $4.99 \%$, indicating that SDS has better performance stability and smaller discreteness.

6.3. Compressive Resilient Modulus. The CRM of SDS and FDS was tested in parallel. In order to make the test results representative, a set number of repeated tests were conducted by using three times the mean square deviation method to eliminate outliers. The mean values of the resilient deformation at 6 loading levels are listed in Table 11, and the relation curve between progressively pressure and resilient deformation is shown in Figure 16.

It can be seen from Figure 16 that the CRM results of SDS and FDS are similar. Modifying the false deformation of curve in Figure 16 according to Chinese specification JTG E51 [36], the CRM was calculated using (3). The calculation results are as follows: The CRM values of SDS and FDS were $1010 \mathrm{MPa}$ and $1130 \mathrm{MPa}$, respectively. During the curing period of 90 days, there is a protracted and complex physical and chemical reaction between cement and the reactive $\mathrm{SiO}_{2}$, $\mathrm{Al}_{2} \mathrm{O}_{3}, \mathrm{CaO}$, and $\mathrm{Fe}_{2} \mathrm{O}_{3}$ in oil shale semicoke, resulting in additional filling and bonding effect, which contributes to the increase of the stiffness performance of samples.

6.4. Frost Resistance. The results of freezing-thawing tests with 5 freeze-thaw cycles are shown in Table 12. It is observed that the BDR and mass loss rate of FDS are $82.28 \%$ and $1.7 \%$, respectively, while the BDR and mass loss rate of SDS are $91.1 \%$ and $0.7 \%$, respectively. Therefore, it can be said that cement-stabilized oil shale semicoke mixture shows good frost resistance, and SDS has better frost resistance than FDS.

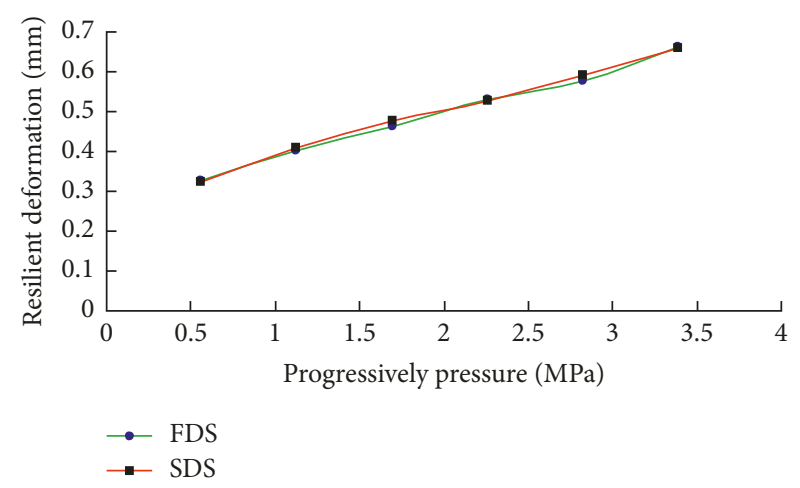

FIGURE 16: The relation curve between progressively pressure and resilient deformation.

TABLE 12: The results of freezing-thawing tests.

\begin{tabular}{lcccc}
\hline & $R_{\mathrm{c}}(\mathrm{MPa})$ & $R_{\mathrm{DC}}(\mathrm{MPa})$ & BDR $(\%)$ & Mass loss rate $(\%)$ \\
\hline FDS & 5.36 & 4.41 & 82.28 & 1.7 \\
SDS & 6.51 & 5.93 & 91.10 & 0.7 \\
\hline
\end{tabular}

\section{Conclusions}

In this paper, the suitability of cement-stabilized oil shale semicoke as a road base or subbase course construction material was investigated, and the following conclusions are reached:

(1) The UCS at 7 days of cement-stabilized oil shale semicoke could satisfy Chinese subbase requirements of all highway grades and traffic grades and base requirements of highway with lower grade or lighter traffic.

(2) The CRM values of SDS and FDS at 90-day curing time could reach $1010 \mathrm{MPa}$ and $1130 \mathrm{MPa}$, respectively. The STS of SDS and FDS at 90-day curing time are $0.65 \mathrm{MPa}$ and $0.46 \mathrm{MPa}$, respectively. The results of freezing-thawing tests indicate that cement-stabilized oil shale semicoke shows good frost resistance. Oil shale semicoke contains pozzolanic reactive $\mathrm{SiO}_{2}, \mathrm{Al}_{2} \mathrm{O}_{3}, \mathrm{CaO}$, and $\mathrm{Fe}_{2} \mathrm{O}_{3}$, which is responsible for the positive performance of cement-stabilized oil shale semicoke mixture.

(3) The SDS mixtures presented better mechanical characteristics than those of FDS throughout the laboratory tests. It is because the crushing value of oil shale semicoke is larger than natural gravel, while FDS contains more coarse aggregate of oil shale semicoke than SDS. When the bond strength of cement increases rapidly with the curing time, locally 
crushed coarse aggregate has decisive influence on the sample failure.

(4) An appropriate mix of cement-stabilized oil shale semicoke with the gradation of SDS can be prepared for construction of various subbase course or base course with lower grade or lighter traffic, enabling the use of these waste materials in highway construction. Additionally, it is of great significance in broadening the pavement material source, eliminating environmental hazards, and recycling oil shale semicoke wastes.

Further investigation on cement-stabilized oil shale semicoke-gravel mixes as a highway construction material is in progress.

\section{Conflicts of Interest}

The authors declare that there are no conflicts of interest regarding the publication of this paper.

\section{Acknowledgments}

The authors express their appreciation for financial supports of National Natural Science Foundation of China (Grant no. 51478203); Transportation Science and Technology Project of Jilin Province, which research on strengthening technology of small and medium span beams based on the transverse tension prestressed method; and Training Program for Outstanding Young Teachers of Jilin University.

\section{References}

[1] C. Zou, Z. Yang, J. Cui et al., "Formation mechanism, geological characteristics and development strategy of nonmarine shale oil in China," Petroleum Exploration and Development, vol. 40, no. 1, pp. 15-27, 2013.

[2] C. Chen, "The new model of mining oil shale in Jilin province," China Mining Magazine, vol. 16, no. 5, p. 55, 2007.

[3] J. Bai, Z. Bai, Q. Wang, and S. Li, "Process simulation of oil shale comprehensive utilization system based on Huadiantype retorting technique," Oil Shale, vol. 32, no. 1, pp. 66-81, 2015.

[4] H. Qin, Y. Yue, H. Liu, and Q. Wang, "Current status and prospect of oil shale retorting technologies in China," Chemical Industry and Engineering Progress, vol. 34, no. 5, pp. 1191-1198, 2015.

[5] L. Pllumaa, A. Maloveryan, M. Trapido, H. Sillak, and A. Kahru, "Study of the environmental hazard caused by the oil shale industry solid waste," Alternatives to Laboratory Animals, vol. 29, no. 3, pp. 259-267, 2001.

[6] H. Raave, S. Kapak, and K. Orupld, "Phytotoxicity of oil shale semi-coke and its aqueous extracts: a study by seed germination bioassay," Oil Shale, vol. 24, no. 1, pp. 59-71, 2007.

[7] L. Vallnera, O. Gavrilovab, and R. Vilub, "Environmental risks and problems of the optimal management of an oil shale semi-coke and ash landfill in Kohtla-Järve, Estonia," Science of the Total Environment, vol. 524-525, pp. 400-415, 2015.

[8] K. Brendow, "Global oil shale issues and perspectives," Oil Shale, vol. 20, no. 1, pp. 81-92, 2003.
[9] H. Liu, W. Liang, H. Qin, and Q. Wang, "Synergy in cocombustion of oil shale semi-coke with torrefied cornstalk," Applied Thermal Engineering, vol. 109, pp. 653-662, 2016.

[10] Y. Yang, X. Lu, and Q. Wang, "Investigation on the cocombustion of low calorific oil shale and its semi-coke by using thermogravimetric analysis," Energy Conversion and Management, vol. 136, pp. 99-107, 2017.

[11] Q. Wang, Y. Xuan, H. Liu, X. Li, and M. Chi, "Gaseous emission and thermal analysis during co-combustion of oil shale semi-coke and sawdust using TG-FTIR," Oil Shale, vol. 32, no. 4, pp. 356-372, 2015.

[12] H. Fadaei, M. Sennoune, S. Salvador, A. Lapene, and G. Debenest, "Modelling of non-consolidated oil shale semicoke forward combustion: Influence of carbon and calcium carbonate contents," Fuel, vol. 95, pp. 197-205, 2012.

[13] B. An, W. Wang, G. Ji et al., "Preparation of nano-sized a- $\mathrm{Al}_{2} \mathrm{O}_{3}$ from oil shale ash," Energy, vol. 35, no. 1, pp. 45-49, 2010.

[14] L. Zhang, X. Zhang, S. Li, and Q. Wang, "Comprehensive utilization of oil shale and prospect analysis," Energy Procedia, vol. 17, pp. 39-43, 2012.

[15] S. H. Aljbour, "Production of ceramics from waste glass and Jordanian oil shale ash," Oil Shale, vol. 33, no. 3, pp. 260-271, 2016.

[16] M. M. Smadi and R. H. Haddad, "The use of oil shale ash in Portland concrete," Cement and Concrete Composites, vol. 25, no. 1, pp. 43-50, 2003.

[17] H. Liu, X. Sun, C. Jia, H. Qin, and Q. Wang, "Analysis of mineral composition of oil shale semicoke and its cocombustion performance with cornstalks," Transactions of the Chinese Society of Agricultural Engineering, vol. 32, no. 10, pp. 226-231, 2016.

[18] L. M. Raado, R. Kuusik, T. Hain, M. Uibu, and P. Somelar, "Oil shale ash based stone formation-hydration, hardening dynamics and phase transformations," Oil Shale, vol. 31, no. 1, pp. 91-101, 2014.

[19] L. M. Raado, T. Hain, E. Liisma, and R. Kuusik, "Composition and properties of oil shale ash concrete," Oil Shale, vol. 31, no. 2, pp. 147-160, 2014.

[20] H. Al-Massaid, T. Khedaywi, and M. Smadi, "Properties of asphalt-oil shale ash bituminous mixtures under normal and freeze-thaw conditions," Journal of the Transportation Research Board, vol. 1228, no. 1228, pp. 54-62, 1989.

[21] A. A. A. Molenaar, S. Akbarnejad, and L. J. M. Houben, "Performance of pavements with blast furnace base courses," in Proceedings of Geoshanghai International Conference, vol. 2010, pp. 476-483377, Shanghai, China, June 2010.

[22] S. P. Singh, D. P. Tripathy, and P. G. Ranjith, "Performance evaluation of cement stabilized fly ash-GBFS mixes as a highway construction material," Waste Management, vol. 28, no. 8, pp. 1331-1337, 2008.

[23] A. K. Sharma and P. V. Sivapullaiah, "Strength development in fly ash and slag mixtures with lime," in Proceedings of the Institution of Civil Engineers: Ground Improvement, vol. 169, pp. 194-205 no. 3, London, UK, August 2016.

[24] F. J. Wang, J. Luo, and H. R. Zhu, "Experimental study in gangue base-course mixture materials for pavement," $A d$ vanced Materials Research, vol. 860-863, pp. 1270-1273, 2013.

[25] H. Z. Zhang, P. F. Cheng, H. J. Shao, and L. Wang, "Test research on temperature shrinkage performance of cement and cinder stabilized coal gangue base course materials," Journal of Highway and Transportation Research and Development, vol. 24, no. 11, pp. 29-32, 2007. 
[26] P. F. Cheng and H. Z. Zhang, "A study on anti-cracking performance of cement stabilized coal gangue," Highway, vol. 52, no. 10, pp. 85-88, 2007.

[27] M. Pasetto and N. Baldo, "Experimental evaluation of high performance base course and road base asphalt concrete with electric arc furnace steel slags," Journal of Hazardous Materials, vol. 181, no. 1-3, pp. 938-948, 2010.

[28] M. Pasetto, A. Baliello, G. Giacomello, and E. Pasquini, "Rheological characterization of warm-modified asphalt mastics containing electric arc furnace steel slags," Advances in Materials Science and Engineering, vol. 2016, Article ID 9535940, 11 pages, 2016.

[29] I. Androjić and S. Dimter, "Compressive strength of steel slag stabilized mixes," Gradevinar, vol. 64, no. 1, pp. 15-21, 2012.

[30] X. Zhang and K. Ren, "Experimental study on strength and thermal conductive characteristics of cement stabilized cinder base," Non-Metallic Mines, vol. 40, no. 4, pp. 47-49, 2017.

[31] D. Liu, L. Li, and H. Cui, "Pavement performance of cement stabilized municipal solid waste incineration bottom ash aggregate and crushed stones," Journal of Tongji University (Natural Science), vol. 43, no. 3, pp. 405-409, 2015.

[32] F. Qin, Z. B. He, and Q. N. Huang, "Research on the corrosion resistance of manganese slag cement stabilized macadam base," Advanced Materials Research, vol. 280, pp. 13-18, 2011.

[33] Ministry of Communications of the People's Republic of China, Test Methods of Aggregate for Highway Engineering, JTG E42, Ministry of Communications, Beijing, China, 2005.

[34] CIQ China Inspection and Quarantine, Standardization Administration of China, Common Portland Cement, GB175, CIQ China, Beijing, China, 2007.

[35] Ministry of Communications of the People's Republic of China, Specifications for Design of Highway Asphalt Pavement, JTG D50, Ministry of Communications, Beijing, China, 2006.

[36] Ministry of Communications of the People's Republic of China, Test Methods of Materials Stabilized with Inorganic Binders for Highway Engineering, JTG E51, Ministry of Communications, Beijing, China, 2009.

[37] Ministry of Communications of the People's Republic of China, Technical Guidelines for Construction of Highway Roadbases, JTG/T F20, Ministry of Communications, Beijing, China, 2015. 


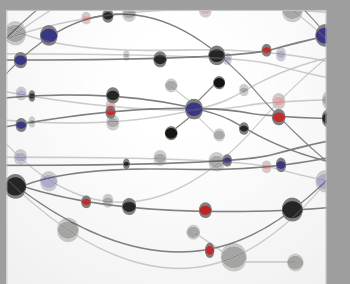

The Scientific World Journal
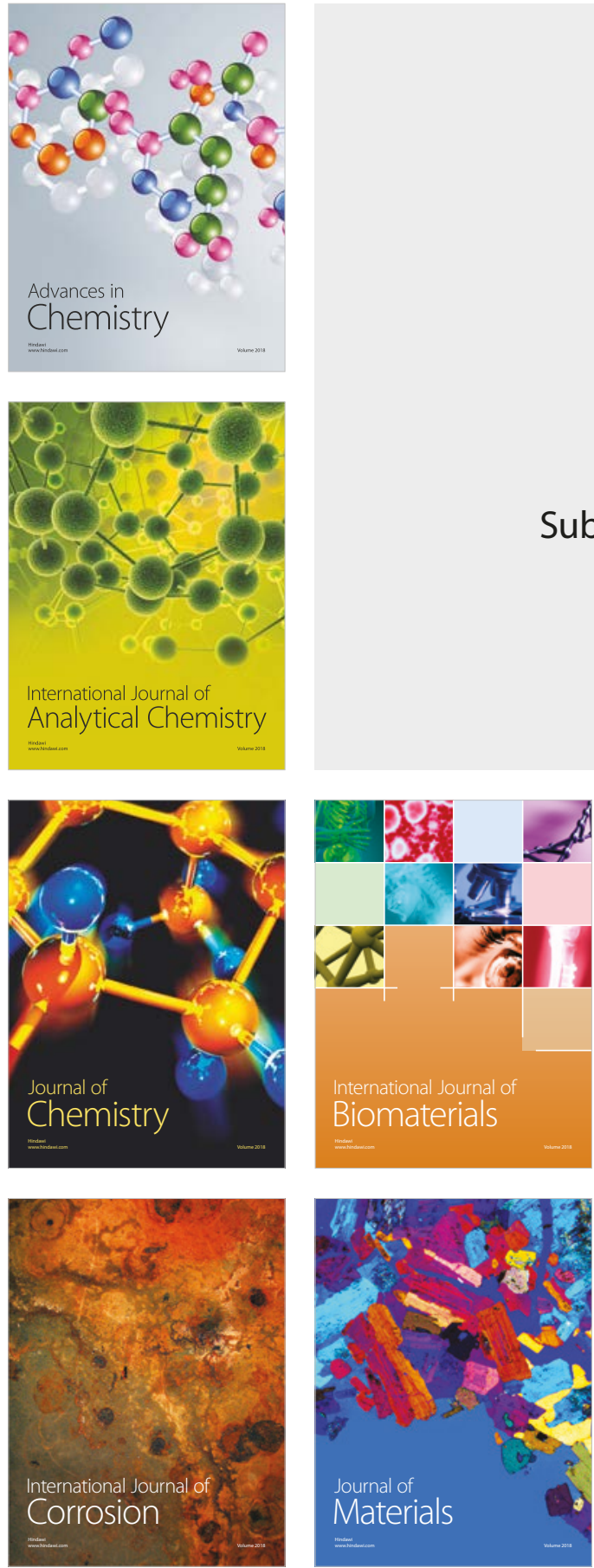

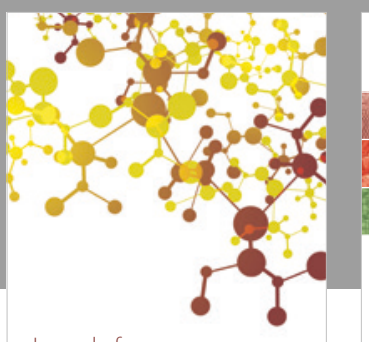

Journal of

Applied Chemistry
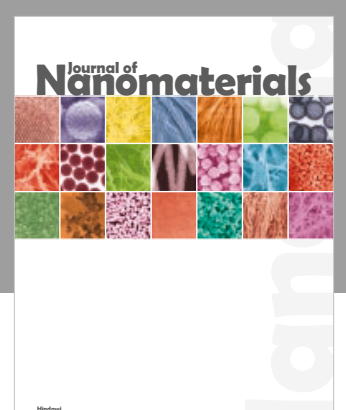

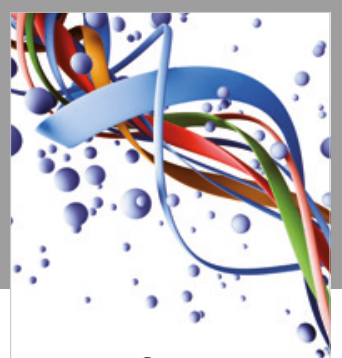

Scientifica

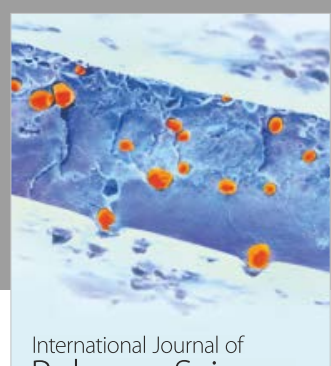

Polymer Science

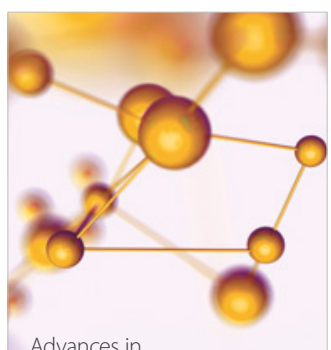

Physical Chemistry
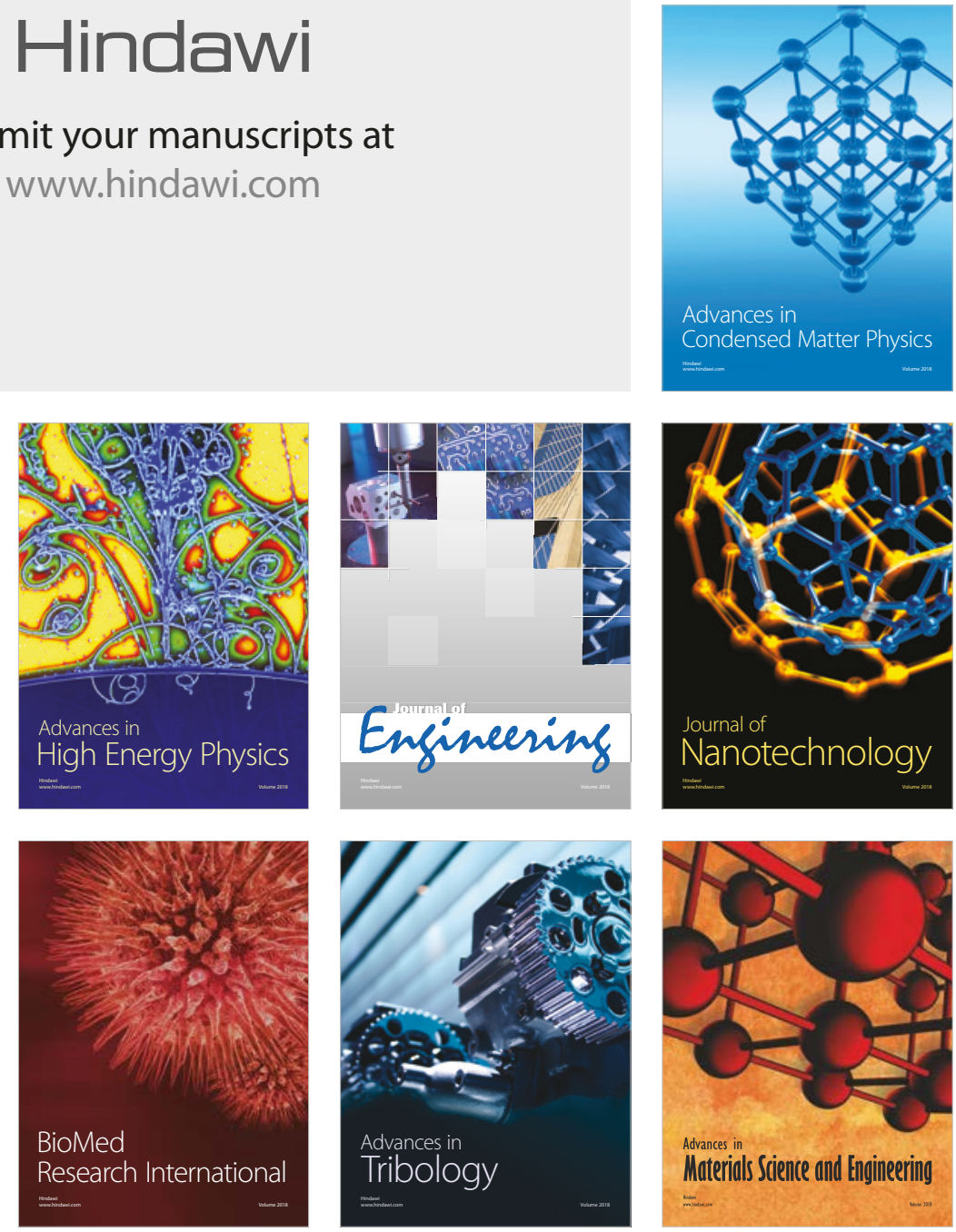